education remains a significant open question.

Apart from these financial issues, other challenges identified by the DAAD and other observers remain to be addressed. These include ensuring that standards for quality research, instruction, and study are maintained in the face of increased competition; ensuring that the curriculum and learning experience for students who are unable to study abroad substantively incorporates elements of internationalization; adjusting the higher education admissions process in order to open up new and more diverse educational pathways for incoming students; and taking advantage of novel learning opportunities presented by new media and innovative technologies. In institutions in more rural locations, the distribution of resources necessary for attracting foreign talent and increasing services for mobility of faculty also remain unevenly distributed. Finally, the development of virtual mobility through massive open online courses and the development of satellite campuses and joint and double-degree programs have not yet made significant headway into various federal policies. Creating additional monitoring systems and research chairs for internationalization may be one way to further develop the process of internationalization in Germany, much as has been done in other large higher education systems.

\section{India's Emergence as a Regional Education Hub}

\section{Mona KHARE}

Mona Khare is Professor at the Centre for Policy Research in Higher Education and in the Department of Educational Planning, at the $\mathrm{Na}$ tional University of Educational Planning and Administration, New Delhi, India. E-mail: monakhare@nuepa.org; mona_khare@rediffmail.com.

Tndia's move from being a North-South recipient to being a South-South, North-South, and triangular cooperation nation is seen as the result of increasing globalization and internationalization of education worldwide. However, increasing South-South cooperation is being seen more as a fallout from the formation of regional blocs, such as the South Asian Association for Regional Cooperation (SAARC); the Association of South East Asian Nations (ASEAN); BRICS (Brazil, Russia, India, China, and South Africa); the trilateral agreement between India, Brazil, and South Africa (IBSA); and the E-9 (education) initiative, whereby 9 member countries (Bangladesh, Brazil, China, Egypt, India, Indonesia, Mexico, Nigeria, and Pakistan) have come together with support from UNESCO, UNICEF, the United Nations Population Fund, and the World Bank to promote joint commitment toward strengthening educational ties. Initiatives—such as India's "Look East" policy, and many others-have further consolidated and strengthened relations between India and its neighboring countries with similar backgrounds and facing similar challenges. As a result, India is not only emerging as an economic leader in the region but its potential as an academic leader is also being recognized.

The post-I990 liberalization policy in India had a profound influence in opening up the education sector via greater collaborations and increased academic mobility of students, researchers, teachers, and academicians. In order to provide greater impetus to internationalization, regulations have been liberalized to allow twinning arrangements with foreign universities and opening campuses abroad. There is also an increasing desire and practice in Indian education institutions of hiring professionals from foreign education systems on attractive remunerations for shortterm engagements. One result of this has been a conscious drive toward harmonization of curricula, assessment methodology, and standardization and accreditation mechanisms to encourage mutual recognition of degrees and credit transfer. This move has been an influencing factor in India emerging as a regional education hub in recent years.

\section{IndiA: An HISTORIC DONOR}

India's involvement in education cooperation with South Asian and African countries can be traced back to several initiatives. Examples include its educational aid program to Nepal in the I950s, the Technical Co-operation Scheme (TCS) under the Colombo Plan, the Indian Technical and Economic Cooperation Scheme (ITEC) that has been functioning since 1964, and the Special Commonwealth African Assistance Program (SCAAP) through which India has provided assistance to more than I5O countries in Asia, East Europe, Africa, and Latin America. According to the Ministry of External Affairs, India spends around Rs500 million (US\$IImillion) annually on ITEC scheme activities, training around 3,000 people in the South each year. Funding through ITEC and SCAAP together has amounted to nearly US\$2 billion since their inception.

Both ITEC and its sister program, SCAAP, use the same aid modalities, but whereas ITEC reaches I42 countries across Asia, Africa, Eastern Europe, Latin America, the Caribbean, the Pacific as well as some small island nations, SCAAP targets only African countries in the Commonwealth (currently I9). ITEC and SCAAP aid comprises five 
different modalities: training of personnel in India, project aid, technical assistance, study trips, and humanitarian assistance. India provides to all African countries with which it maintains diplomatic relations a certain amount of SCAAP/ITEC units that may be converted into aid via the afore-mentioned modalities. Having said that, the work of the programs was largely limited to capacity development and technical training/education as a demand side programmatic support. It is only in the last two decades that India has started targeting neighboring nations for academic support in a broader sense.

\section{Recent Trends and Endeavors}

India's potential as an academic leader is slowly building as its international education cooperation arena widens. India is trying to leverage its comparative advantage in the region in multiple ways in order to be recognized as a rising educational hub. The newer modes of collaborative ventures are testimony to the fact that India is all set to change its image as a source nation to a sought-after destination country-more so in Asia and Africa. Numerous attempts are being made via various schemes to attract foreign students to the country. The following efforts in recent years provide a subtle insight into this new dimension.

India as a Preferred Asian Destination. Until recently, India was only recognized as a major source country as far as international student mobility was concerned, but the past few years have seen an impressive growth in the number of foreign students coming to India. From a mere 6,988 in 2000 , it grew to $27,53 \mathrm{I}$ in $201 \mathrm{I}$ and then further to 33,156 in 2OI2, thus registering an increase of almost 2I percent in just one year. Although students are coming from more than I50 nations, the greater number is from Asia. The 2OII-2OI2 All India Survey on Higher Education cites the top Io sender countries to India as being Nepal, Bhutan, Iran, Afghanistan, Malaysia, Sri Lanka, Sudan, Iraq, China, and the United States. These Io together accounted for ${ }_{2}$ percent of the total number of foreign students in the country. UNESCO statistics show that the preferred destination of a large number of SAARC nation students is India, which figures much higher than other foreign destinations. These students are from Bhutan (7I percent), Nepal (I9 percent), Afghanistan ( 6 percent), and the Maldives (I4 percent).

Most students come to India to pursue undergraduate degrees and only a small number undertake doctoral programs. The main reason for the increase in foreign students coming to India for undergraduate education may be the high pace of India's higher education expansion in the past few years - by way of opening undergraduate and professional colleges - alongside a comparatively small higher education sector in its neighboring countries. Other fac- tors contributing to this growth are geographical closeness, similar cultural underpinnings, plus the fact that the education experience is affordable-due not just to lower fees compared with other developed nations in the West and the Asian region but also to lower living expenses.

Systematic Partnerships in the Region. Although India has equally intensified and systematized its partnerships with the developed countries of the West, its regional focus in forging larger and larger numbers of international collaborations is evident from the fact that, of the i2 educational exchange programs/memoranda of understanding (EEPs/ MOUs) signed during the last three years, 8 are with Asian and African countries. These include Mauritius, Yemen, Tajikistan, Burundi, Belarus, Trinidad and Tobago, and the Republic of Korea. Not only have the number of EEPs/ MOUs signed in recent years increased manifold (currently totaling 48), the majority of them are with developing Asian and African nations, which look to India for leadership.

Development of Regional Multi-Country Universities/Centers. Such centers are the outcome of an increasing number of regional associations. Two institutions that have been set up under the aegis of the two most important regional associations deserve a special mention here. These are the South Asian University, set up by SAARC member nations, and the Mahatma Gandhi Institute of Education for Peace and Sustainable Development, a UNESCO Category I institute in the Asia-Pacific region, both located in New Delhithe Indian capital city.

Distance Education Network. India's largest open university, the Indira Gandhi National Open University, has almost 300 study centers in 38 countries located for the most part in Africa, Central Asia, and the Persian Gulf region. In addition, there are many other private management and professional institutes offering programs to foreign nationals via distance education.

Campuses Abroad. A small number of Indian educational institutions have branch campuses operating abroad, for example Birla Institute of Technology and Science in Dubai; Manipal University campus in Dubai, Malaysia, and elsewhere; and the SP Jain School of Global Management in Dubai, Singapore, and Sydney. In fact, Dubai is home to some of the leading names in India. The presence of a large South Asian expatriate population in Dubai, alongside growing host nation demand, are often cited as reasons why many Indian campuses have been operative there for many years. Furthermore, the number of overseas Indian branch campuses in other countries is growing fast, according to the Observatory on Borderless Higher Education. India leads 
in overseas higher education provision from non-Western countries, with more than I7 campuses abroad-io of these in the United Arab Emirates, 4 in Mauritius, and the others in Malaysia, Singapore, and countries in the West.

The scope is wide for both private as well as public institutions, to open many more such campuses abroad, given their wide acceptance in the region. At the moment, it is predominantly private education providers who are exploring greener pastures to increase their higher education market share and profit, by widening their geographical base. Private education providers charge much higher fees than their public counterparts, and the fact that there is rapid growth in education provision abroad by private Indian providers suggests that students are prepared to pay these high fees to take Indian degrees outside India.

\section{Engagement Through Short-Term Programs/Summer}

Schools. In an attempt to provide opportunities to undergraduate students from other countries, the "Connect to India" program funded by the Government of India has been initiated with the aim of fostering international goodwill through young students. Selected public universities of repute have been identified to offer short-term courses by way of summer schools in different disciplines from the June-July 20I4-20I5 academic session onwards. The courses would aim at providing a better understanding of contemporary India, its rich artistic and cultural heritage, its economic and technological progress, and so forth. The program would include visits to historical places and opportunities of greater community interaction through participation in cultural programs, yoga classes, and so on.

Recognition of Non-Indian High School Certification. As most students coming to India intend to join bachelor's degree programs, the Government of India has already accorded equivalence to some of the most popular systems of school education in the world and continues to add to the list in order to facilitate their entry into tertiary level education.

The evaluation unit of the Association of Indian Universities has been engaged in the work of providing academic equivalence to degrees/diplomas from foreign countries for the last 88 years. The unit is carrying out this work alongside the standardized assessment of accredited foreign university qualifications for bilateral agreements for student/faculty exchange within a traditional education exchange program involving various countries, which has been ongoing for many years and has produced a constant growth of student and faculty numbers.

\section{CONCLUSION}

Now that India's popularity as a higher education provider in the region is growing, it is the right time for India to consolidate its newfound regional educational leadership. Moving from an undergraduate education hub to a postgraduate and doctoral hub would help India to be recognized as a leader in the knowledge creation industry. Attempts to attract more students for postgraduate and doctoral studies-by way of starting SAARC, ASEAN, and other regional research centers, promoting cross-cultural interdisciplinary studies-can go a long way in furthering regional educational ties. As most of the countries in these areas are developing and have a very limited or small higher education sector, India should explore the possibilities of greater use of Information and Communication Technology to reach out to a larger student community in neighboring countries. Some other areas that demand harmonization in a global education scenario are the development of capacities to define and implement standardization/accreditation/assessment of learning achievements, the improvement of basic numeracy and English language skills, curriculum development and innovation, the development of teaching-learning materials, and the sensitization and promotion of inclusion in classroom practices. Given the gravity of the challenge of the employability skills gaps among youth in Asia and Africa, the provision of high-quality technical and vocational education and training programs is yet another area over which India's academic leadership can have a positive influence. For all of this to become a reality and at the same time give India a comparative advantage over other neighboring nations, India needs to strategically roll out its long-term plan with far-reaching goals and specific time-bound priorities.

\section{Internationalization Trends} in French Higher Education:
An Historical Overview

\section{Guillaume Tronchet}

Guillaume Tronchet is professeur agrégé d'histoire and research associate at the Paris Centre for zoth Century Social History. He also maintains the French blog Chroniques de diplomatie universitaire on educpros.fr. E-mail: gtronchet@gmail.com.

For many policymakers in France, internationalization of 